Самолюк Н. М., к.е.н., доцент (Національний університет водного господарства та природокористування, М. Рівне), Костюк Д. О., член Рівненської Малої академії наук учнівської молоді

\title{
СТАН ТА ПЕРСПЕКТИВИ РОЗВИТКУ ФРІЛАНСУ В УКРАЇНІ
}

В даній статті розглянуто основні мотиви фріланс-діяльності на основі аналізу опитувань фрілансерів. Досліджено тенденції розвитку ринку фрілансу в Україні, зокрема в розрізі міст. Охарактеризовано розподіл українських фрілансерів за сферою діяльності. Проаналізовано розмір та динаміку заробітку працівників даної форми зайнятості. Розглянуто основні перешкоди, що виникають в умовах фріланс-діяльності. Досліджено перспективи розвитку фрілансу в Україні методом SWOT-аналізу.

Ключові слова: фріланс, фрілансер, форма зайнятості, самозайнятість, фріланс-біржа.

Постановка проблеми. Останнім часом у всьому світі спостерігається тенденція до зростання фрілансу. Зокрема, у 20\% організацій, з чисельністю персоналу понад 1000 співробітників, фрілансери становлять не менше 30\% працівників [9]; 20-30\% населення працездатного віку в Сполучених Штатах і Європейському Союзі займаються фрілансом [10]. Крім того, згідно з дослідженням Європейського форуму незалежних професіоналів (European Forum of Independent Professionals, EFIP), з 2000 року кількість фрілансерів в Європі зросла на $82 \%$.

Світовими лідерами поширеності фрілансу є США, Австралія та Великобританія. Наприклад, з 2008 по 2016 рік чисельність фрілансерів у Великобританії зросла на $43 \%$ і становила 2 млн осіб (6\% робочої сили країни); їх діяльність принесла в економіку країни 119 млрд фунтів стерлінгів [8]. Що стосується України, то за результатами дослідження кадрового порталу rabota.ua, кожен п'ятий опитаний на сьогоднішній день працює на умовах фрілансу. Проте бажаючих стати фрілансером набагато більше - 92\% респондентів [4]. При цьому, за прогнозами експертів до 2020 р. майже $50 \%$ найманої робочої сили в світі буде працювати на умовах фрілансу.

Аналіз останніх досліджень. Питання нових форм зайнятості, зокрема фрілансу, вивчається багатьма зарубіжними та вітчизняними вченими. Так, дослідженню особливостей фрілансу присвяченні праці Кузьміна О.Є., Скибіцького О.С., Солярчук Н.Ю. [6], аналізу тенденцій його розвитку - Божкової К. [1] та Малик І. [4]. Оцінка проблем фрілансу в Україні розглядається Ілляшенком С.М. [2]. Різні міжнародні організації та інститути проводять регулярні опитування і зведе- 
ну аналітичну інформацію розміщують на своїх сайтах та у виданнях [7; 8; 9]. Водночас питання аналізу основних проблем на ринку фрілансу та можливостей його подальшого розвитку і надалі лишається актуальним.

Постановка завдання. Враховуючи зазначене, метою цієї роботи є дослідження стану, мотивів та перспектив розвитку фрілансу в Україні як альтернативної форми зайнятості.

Виклад основного матеріалу. На даний час не існує єдиного підходу до визначення сутності поняття «фріланс», проте найчастіше воно означає форму зайнятості, при якій працівник не зараховується до штату організації, виконуючи роботу через мережу Інтернет. Тому популярними видами діяльності, які реалізуються на умовах фрілансу $є$ ті, що без будь-яких проблем виконуються віддалено від стаціонарного робочого місця в організації, а саме: дизайн (розробка логотипів, графічний дизайн, дизайн сайтів тощо), мультимедіа, створення контенту сайтів (написання блогів, статей, контент маркетинг), програмування, розробка мобільних додатків (iOS, Android і т.п.), адміністрування, переклад, продажі і маркетинг (зокрема, Social Media Marketing), інжиніринг [2].

На думку експертів, нова форма зайнятості, що приносить хороші доходи, вимагає появи особливої інфраструктури. Наприклад, в США активно з'являються онлайн-біржі праці, коворкінгові простори, команди і кооперації фрілансерів. Також функціонують групи підтримки, такі як Freelancers Union (Союз фрілансерів в США). Це стало можливим, тому що фріланс став альтернативною традиційній формою зайнятості, що є надзвичайно привабливою як для роботодавців, так і для безпосередніх виконавців робіт [7].

Результати дослідження компанії Ameritrade, наведені на рис. 1, показали, що переважна більшість фрілансерсів (57\%) до причин своєї фріланс-діяльності віднесли можливість вільно розпоряджатися графіком роботи. Поряд з цим, достатньо значимими причинами розвитку фрілансу $є$ відсутність «начальства» (46\%), можливість працювати над цікавими проектами (39\%) і отримувати задоволення від роботи (31\%). Аналогічне дослідження, проведене кадровим порталом rabota.ua, серед основних мотивів фріланс-зайнятості виявило: можливість розпоряджатися власним часом (66\% опитаних), можливість регулювати рівень доходів за рахунок збільшення або зменшення замовлень (51\%), можливість працювати віддалено не витрачати час на переїзд і «нерви на пробки» (42\%). Варто зазначити, що також багато респондентів сприймають фріланс як реальне джерело додаткового доходу, який можна отримувати понад основний дохід на стаціонарному робочому місці, або як можливість отримання та відпрацювання нових професійних навичок [4]. 


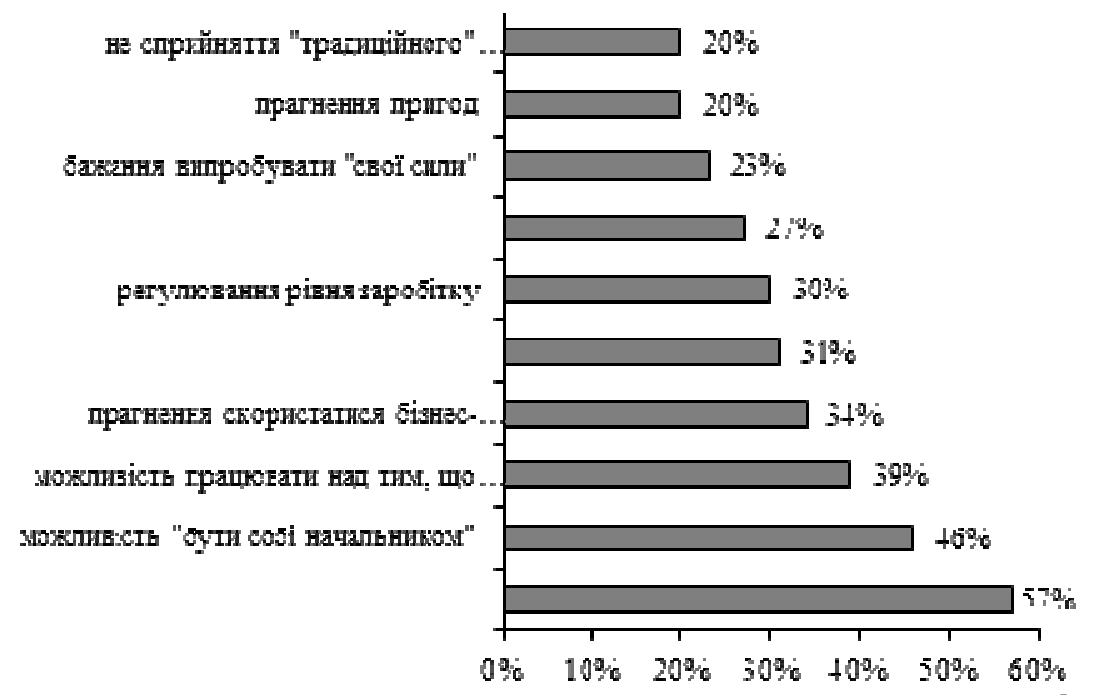

Рис. 1. Розподіл респондентів за причинами фріланс-діяльності [3; 6]

Як не дивно, але до європейських країн з найбільшою кількістю фрілансерів належить Україна, Росія та Румунія. За даними рекрутингової компанії Top\$Dev частка українських фрілансерів на європейському ринку становить 22,9\%. При цьому, найбільшим попитом фріланс-послуги наших співвітчизників користуються в англомовних регіонах. Зокрема, до топ-5 країн за кількістю працевлаштованих фрілансерів з України входять США, Великобританія, Австралія, Канада та Німеччина (рис. 2).

В Україні, ринок фрілансу активно почав свій розвиток ще в 2006 році, але стрімке збільшення розпочалось з 2011 року. Для порівняння за період з 2006 по 2011 рік фрілансери заробили близько 38 млн дол, а вже з 2012 по 2017 рік - 262 млн дол. Тож, загалом, це 300 млн дол. за останні 10 років. При цьому, саме за останні 5 років заробіток фрілансерів зріс на 49\% [1].

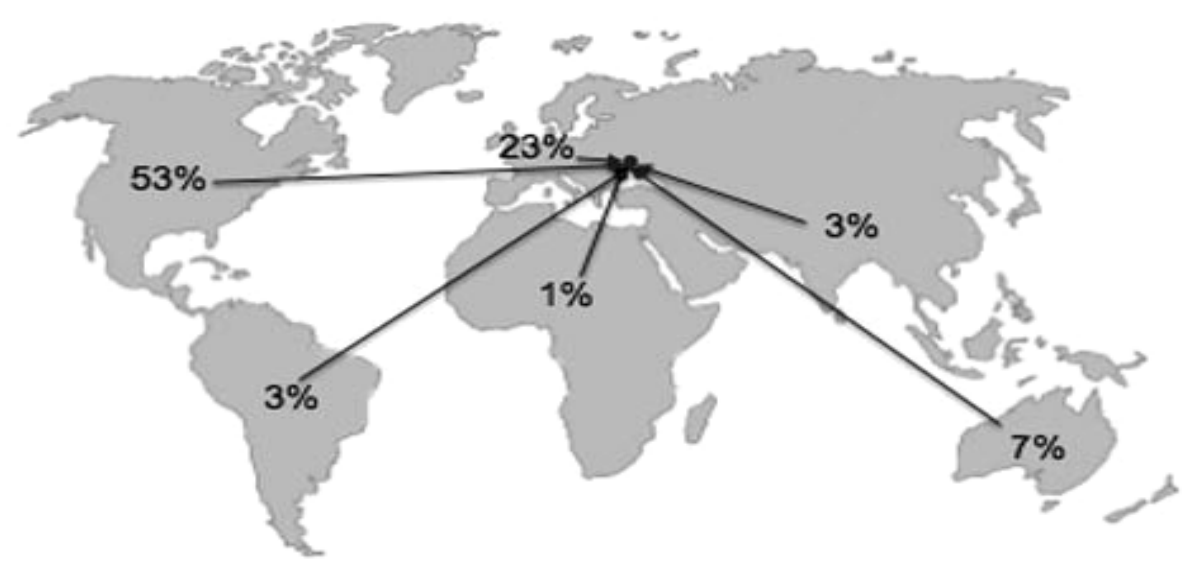

Рис. 2. Країни-роботодавці українських фрілансерів 
Впродовж 2011-2016 років в Україні на фріланс-біржах зареєструвалося майже 190 тис. фрілансерів (статистика Upwork). Однак, 3 них активно на постійній основі працює лише $25 \%$ - 54 тис. осіб. Динаміку чисельності фрілансерів та їх заробітку проілюстровано на рис. 3.

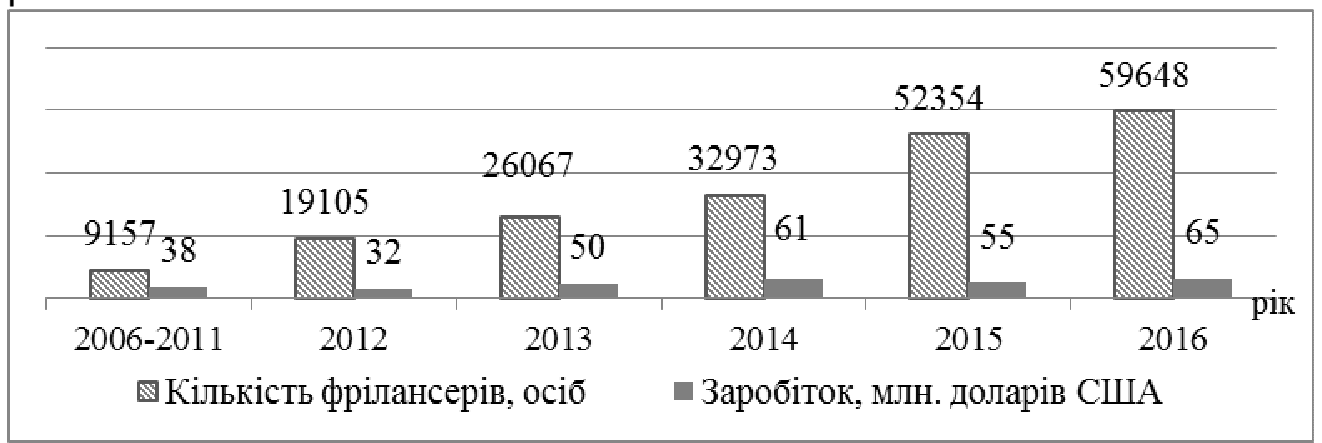

Рис. 3. Динаміка чисельності фрілансерів та їх заробітку в Україні [1]

Лідером за чисельністю фрілансерів в Україні є місто Київ. При цьому за заробітком лідирує місто Харків, хоча чисельність фрілансерів там менша майже в два рази. Загальна кількість фрілансерів у 6 містах-мільйонниках становить 74,5 тис. осіб. Заробіток фрілансерів у цих містах сумарно за 2012-2016 роки склав \$146 млн. Як бачимо з табл. 1, показники доводять високу активність фрілансерів у ключових містах країни, проте в менших містах їх активність $€$ набагато нижчою. Дане явище пояснюється тим, що у великих містах населення швидше реагує на нові тенденції ринку праці, має більше можливостей для саморозвитку та навчання, а також сприймає фріланс як альтернативну та більш вигідну як з фінансової точки зору, так і з особистих мотивів форму зайнятості.

Таблиця 1

Чисельність та заробіток фрілансерів по містах України (сумарно за 2012-2016 рр.) [1]

\begin{tabular}{|l|c|c|}
\hline \multicolumn{1}{|c|}{ Місто } & Чисельність, осіб & Заробіток, дол. США \\
\hline Харків & 14993 & 54008384,82 \\
\hline Київ & 32332 & 39356826,52 \\
\hline Львів & 8206 & 17663091,42 \\
\hline Дніпро & 3654 & 11008912,9 \\
\hline Запоріжжя & 9865 & 17746786,34 \\
\hline Одеса & 5389 & 6458461,99 \\
\hline Інші міста & 40561 & 17733380,66 \\
\hline
\end{tabular}


Розподіл українських фрілансерів за сферою діяльності досить нерівномірний. Близько $76 \%$ фрілансерів спеціалізуються в сфері програмування, дизайну та на роботі з текстом, і лише $24 \%$ - займаються усіма іншими видами діяльності (рис. 4).

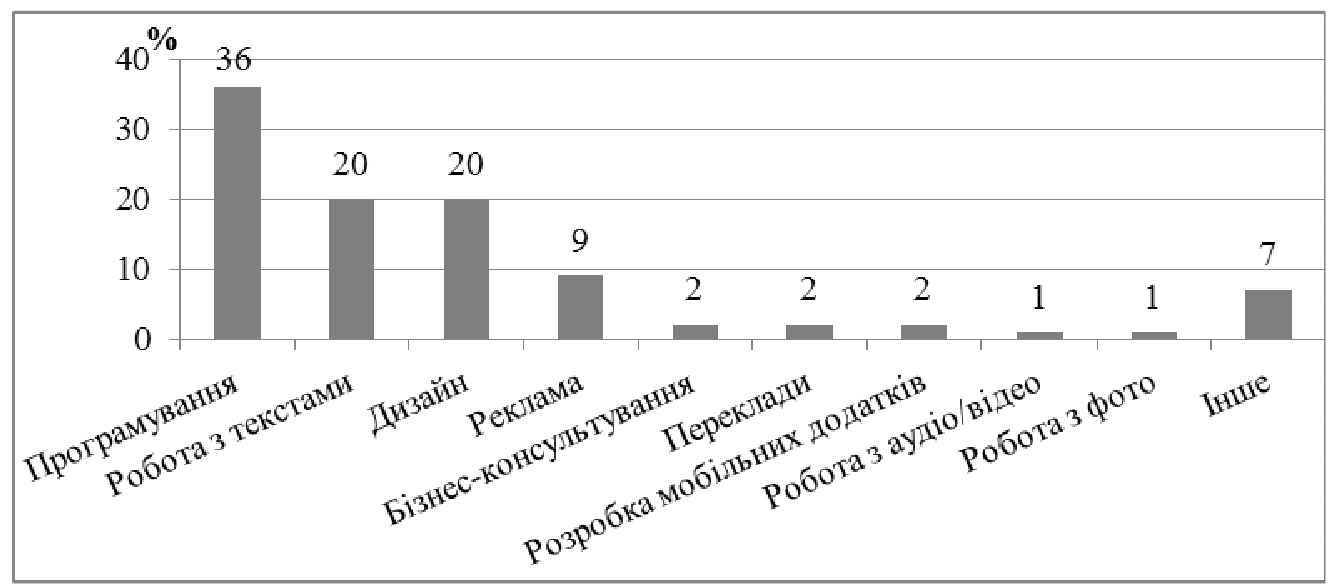

Рис. 4. Сфера діяльності українських фрілансерів [3]

За прогнозами експертів до 2020 року найбільший попит іноземних клієнтів фріланс-бірж буде на такі тренди [1]:

1) Web: AngularJS, React.js, Backbone.js, Ember.js, Python using Django, Ruby on Rails, PHP (no framework), WordPress, Laravel Framework;

2) Mobile: native iOS mobile app development using Objective-C, native Android app development using Java.

Попри позитивні тенденції розвитку фрілансу, результати опитування, проведеного на сайті rabota.ua, виявили ряд перешкод, що виникають в умовах фріланс-діяльності. Серед них можна виділити наступні [4]:

- наявність проблемних замовників, «які самі не знають, чого хочуть» $-43 \%$ опитаних;

- наявність замовників-шахраїв - 29\%;

- невміння себе «продати»-35\%;

- невміння налагодити тайм-менеджмент - 31\%;

- відсутність спілкування та консультування з колегами - 22\%.

Тож, перспективи розвитку фрілансу в Україні варто дослідити, скориставшись методом SWOT-аналізу. Як бачимо з таблиці 2, серед основних загроз розвитку фрілансу знаходиться законодавча неврегульованість даного виду зайнятості. Зокрема у вітчизняному законодавстві відсутні поняття «фріланс» та «фрілансер». Проте Міністерство соціальної політики України в одному із своїх листів визначає «фріланс» як віддалену роботу за допомогою мережі Інтернет, а «фрілансера» - як вільного працівника (самозайняту особу), позаш- 
татного працівника, який виконує разове замовлення або тимчасову роботу без зарахування до штату підприємства [5]. Термінологічна невизначеність на сьогодні створює проблеми щодо визначення правового поля регулювання відносин, документального оформлення, відображення в обліку, а також оподаткування.

Відтак, хоча за своєю економічною природою фріланс є різновидом трудових відносин, проте до фрілансерів не можуть бути застосовані норми трудового права, оскільки такі особи з позиції податкового законодавства є самозайнятими особами і здійснюють незалежну професійну діяльність. Крім того, порядок оподаткування залежить від статусу виконавця таких робіт (рис. 5).

Приведення національного законодавства у відповідність до міжнародних норм переведе проблему оподаткування оплати праці фрілансерів у сферу трудового законодавства. Даний крок дозволить захистити права працівників знизивши ймовірність укладання реально трудових договорів як цивільно-правових, що особливо актуально у світлі значного підвищення рівня відповідальності за порушення у сфері трудового законодавства України. Таким чином окремі загрози розвитку фрілансу буде усунено.

Таблиця 2

SWOT-аналіз розвитку фрілансу в Україні [2]

\begin{tabular}{|c|c|c|}
\hline \multirow{8}{*}{ 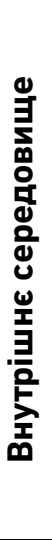 } & Сильні сторони фрілансу (S) & Слабкі сторони фрілансу(W) \\
\hline & $\begin{array}{l}\text { Молоді фахівці з високим рівнем осві- } \\
\text { ти, що не можуть знайти роботу }\end{array}$ & $\begin{array}{l}\text { Постійна самоорганізація і необ- } \\
\text { хідність самому виконувати різно- } \\
\text { планові роботи }\end{array}$ \\
\hline & $\begin{array}{l}\text { Кваліфіковані фахівці, які хочуть пра- } \\
\text { цювати самостійно }\end{array}$ & $\begin{array}{l}\text { Витрати на облаштування робочо- } \\
\text { го місця }\end{array}$ \\
\hline & Високий імідж українських фрілансерів & $\begin{array}{l}\text { Відсутність спілкування } 3 \text { колега- } \\
\text { ми }\end{array}$ \\
\hline & \multirow{4}{*}{ Поширення Інтернету в Україні } & Постійний пошук замовлень \\
\hline & & Відсутність соціальних гарантій \\
\hline & & Нестабільність прибутків \\
\hline & & Ймовірність бути обманутим \\
\hline \multirow{6}{*}{ 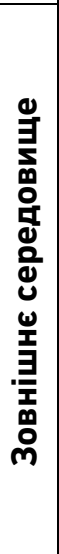 } & Ринкові можливості (0) & Ринкові загрози (Т) \\
\hline & \begin{tabular}{|l|} 
Розширення видів діяльності, які не \\
вимагають присутності працівника
\end{tabular} & $\begin{array}{l}\text { Законодавча неврегульованість } \\
\text { діяльності фрілансерів }\end{array}$ \\
\hline & $\begin{array}{l}\text { Зростання популярності і прибутковос- } \\
\text { ті фрілансу для клієнтів }\end{array}$ & $\begin{array}{l}\text { Необхідність знання іноземних мов } \\
\text { для роботи на зарубіжних ринках }\end{array}$ \\
\hline & $\begin{array}{l}\text { Можливість виходу на міжнародний } \\
\text { ринок і отримання високої зарплати }\end{array}$ & \multirow{3}{*}{$\begin{array}{l}\text { Обмеженість робіт, що можна ви- } \\
\text { конувати на умовах фрілансу }\end{array}$} \\
\hline & $\begin{array}{l}\text { Наявність Інтернет-сервісів для праці- } \\
\text { вників і замовників }\end{array}$ & \\
\hline & $\begin{array}{l}\text { Привабливі умови праці для працівни- } \\
\text { ків, робота яких має творчий характер } \\
\text { чи які схильні до самостійного її вико- } \\
\text { нання }\end{array}$ & \\
\hline
\end{tabular}




\begin{tabular}{|c|c|c|}
\hline \multicolumn{2}{|c|}{$\begin{array}{l}\text { Фрілансер- } \\
\text { фізична особа }\end{array}$} & $\begin{array}{c}\text { ЕСВ -22\%, але не менше мінімального і не більше макси- } \\
\text { мального страхового внеску }\end{array}$ \\
\hline \multirow{4}{*}{ 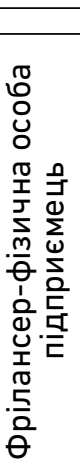 } & \multirow[b]{2}{*}{$\begin{array}{l}\text { Спрощена } \\
\text { система } \\
\text { оподатку- } \\
\text { вання }\end{array}$} & ПДФО - \\
\hline & & $\begin{array}{l}\text { ЄСВ - } 22 \% \text {, але не менше мін. страхового внеску. Якщо дохід } \\
\text { не отримано - визначається самостійно, але не менше } \\
\text { мінімального і не більше максимального страхового внеску }\end{array}$ \\
\hline & \multirow{2}{*}{$\begin{array}{l}\text { Загальна } \\
\text { система } \\
\text { оподатку- } \\
\text { вання }\end{array}$} & $\begin{array}{c}\text { Єдиний податок (ЄП): 3\% (у разі реєстрації платником ПДВ), } \\
\text { ПДВ - 20\%, або 5\% (у разі включення ПДВ до складу ЄП) }\end{array}$ \\
\hline & & $\begin{array}{c}\text { Визначається самостійно, але не менше мінімального і не } \\
\text { більше максимального страхового внеску }\end{array}$ \\
\hline
\end{tabular}

Рис. 5. Оподаткування діяльності фрілансерів [5]

Також варто відмітити, що в напрямку законодавчого регулювання даної форми зайнятості уже робляться перші кроки. Так, 03.11.2016 року, Верховною Радою було прийнято Закон України «Про внесення змін і доповнень до деяких законодавчих актів (щодо усунення адміністративних бар'єрів для експорту послуг)», більш відомий як «Закон про фрілансерів». Він передбачає спрощення процедури укладання зовнішньоекономічних договорів (можливість укладення договору в електронній формі шляхом прийняття публічної оферти, обміну електронними повідомленнями або шляхом виставляння рахунку), фінансової звітності під час експорту послуг, а також скасування валютного контролю щодо операцій з експорту послуг.

Попри зазначенні в табл. 2 слабкі сторони та ринкові загрози, сильні сторони фрілансу в поєднанні з ринковими можливостями свідчать про високі шанси на успіх розвитку даної форми зайнятості в Україні.

Висновки. Розвиток фрілансу однозначно оцінювати не можна. В межах держави фріланс сприяє підвищенню рівня життя населення та залученню соціально вразливих категорій населення до трудової діяльності. Для роботодавця фріланс дає можливість економити кошти на організації робочого місця та легалізації трудових відносин. Попри це існують ризики недобросовісного виконання проекту та втрати авторського супроводу, а також відсутня можливість притягнення недобросовісного виконавця до дисциплінарної відповідальності. Негативним аспектом фрілансу також можна вважати недосконалість законодавчої бази, що призводить до відсутності реєстрації та в подальшому несплати податків. Таким чином, вагома роль у 
становленні ринку фрілансу відводиться саме державі та їі зацікавленості й підтримці даної форми співпраці між працівниками та роботодавцями.

Результати SWOT-аналізу свідчать, що українські фрілансери доволі успішно розширюють свій сегмент міжнародного ринку - для цього у них є всі можливості як зовнішні, так і внутрішні. Високі шанси розвитку в Україні фрілансу, дозволять забезпечити зайнятість працівників, зменшити рівень безробіття, сприяти виходу вітчизняних працівників на світовий ринок праці, а разом з тим підвищать рівень економічної безпеки країни.

1. Божкова Катерина. Как изменился фриланс в Украине за 5 лет: конкуренция, специальности, рейты. URL: https://ain.ua/2017/03/22/kakizmenilsya-frilans-v-ukraine-za-5-let-konkurenciya-specialnosti-rejty (дата звернення : 05.10.2018). 2. Ілляшенко С. М. Розвиток фрілансу як фактор забезпечення економічної безпеки України: оцінка перспектив. Економічна безпека територіально-виробничих комплексів: енергетика, екологія, інформаційні технології : монографія / Коцко Т. А. та ін. ; за наук. ред. д.т.н., проф. Лук'яненка С. О., К.е.н., доц. Караєвої Н. В. К. : «МП Леся», 2015. С. 185-189. 3. Киричок Т. В. Особливості розвитку «фрілансу» в світі та Україні. URL: http://ea.donntu.org:8080/jspui/bitstream/123456789/22056/ 1/kirichok.pdf (дата звернення : 05.10.2018). 4. Малык Ірина. Как чувствует себя фрилансрынок Украины в кризис. URL: https://ubr.ua/labor-market/ukrainian-labormarket/kak-chuvstvuet-sebia-frilans-rynok-ukrainy-v-krizis-359481 (дата звернення : 05.10.2018). 5. Озерова О.Г. Проблеми оподаткування оплати праці фрилансерів. Розвиток соціально-економічних систем в геоекономічному просторі: теорія, методологія, організація обліку та оподаткування : матеріали міжнародної науково-практичної конференції, м. Тернопіль, 11-12 травня 2017 року. Т. : ФОП Паляниця В.А., 2017. С. 177-179. 6. Солярчук Н. Ю. Економіко-демографічна характеристика діяльності фрілансерів у світовій практиці. Конкурентоспроможність в умовах глобалізації: реалії, проблеми та перспективи : зб. матер. VI Міжнар. наук.-практ. конф., м. Житомир, 26-27 квітня 2012 р. Житомир. С. 114-115. 7. 7 трендов мирового рынка фриланca. URL: https://ubr.ua/labor-market/ukrainian-labor-market/7-trendovmirovogo-rynka-frilansa-363882 (дата звернення : 05.10.2018). 8. Exploring the UK Freelance Workforce in $2016 . \quad$ URL: https://www.ipse.co.uk/uploads/assets/uploaded/de84dfb7-283a-4c26ba446f95f5547c1f.pdf (дата звернення : 05.10.2018). 9. Global Contingent Workforce Study, EY. URL: https://gigeconomy.ey.com/ (дата звернення : 05.10.2018). 10. Independent work: Choice, necessity, and the gig economy / McKinsey Global Institute, $2016 . \quad$ URL: https://www.mckinsey.com/ /media/McKinsey/Featured\%20Insights/Employ ment $\% 20$ and $\% 20$ Growth/Independent $\% 20$ work $\% 20$ Choice $\% 20$ necessity $\% 20$ a nd\%20the\%20gig\%20economy/Independent-Work-Choice-necessity-and-the- 
gig-economy-Executive-Summary.ashx (дата звернення : 05.10.2018).

\section{REFERENCES :}

1. Bozhkova Kateryna. Kak yzmenilsia frilans v Ukraine za 5 let: konkurentsyia, spetsyalnosti, reity. URL: https://ain.ua/2017/03/22/kak-izmenilsyafrilans-v-ukraine-za-5-let-konkurenciya-specialnosti-rejty (data zvernennia : 05.10.2018). 2. Illiashenko S. M. Rozvytok frilansu yak faktor zabezpechennia ekonomichnoi bezpeky Ukrainy: otsinka perspektyv. Ekonomichna bezpeka terytorialno-vyrobnychykh kompleksiv: enerhetyka, ekolohiia, informatsiini tekhnolohii : monohrafiia / Kotsko T. A. ta in. ; za nauk. red. d.t.n., prof. Lukianenka S. O., k.e.n., dots. Karaievoi N. V. K. : «MP Lesia», 2015. S. 185-189. 3. Kyrychok T. V. Osoblyvosti rozvytku «frilansu» v sviti ta Ukraini. URL: http://ea.donntu.org:8080/jspui/bitstream/123456789/22056/ 1/kirichok.pdf (data zvernennia : 05.10.2018). 4. Malyk Iryna. Kak chuvstvuet sebia frylansronok Ukrayny v kryzy. URL: https://ubr.ua/labor-market/ukrainian-labormarket/kak-chuvstvuet-sebia-frilans-rynok-ukrainy-v-krizis-359481 (data zvernennia : 05.10.2018). 5. Ozerova 0. H. Problemy opodatkuvannia oplaty pratsi frilanseriv. Rozvytok sotsialno-ekonomichnykh system v heoekonomichnomu prostori: teoriia, metodolohiia, orhanizatsiia obliku ta opodatkuvannia : materialy mizhnarodnoi naukovo-praktychnoi konferentsii, m. Ternopil, 11-12 travnia 2017 roku. T. : FOP Palianytsia V. A., 2017. S. 177-179. 6. Soliarchuk N. Yu. Ekonomiko-demohrafichna kharakterystyka diialnosti frilanseriv u svitovii praktytsi. Konkurentosp-romozhnist $v$ umovakh hlobalizatsii: realii, problemy ta perspektyvy : zb. mater. VI Mizhnar. nauk.prakt. konf., m. Zhytomyr, 26-27 kvitnia 2012 r. Zhytomyr. S. 114-115. 7. 7 trendov myrovoho rynka frylansa. URL: https://ubr.ua/labormarket/ukrainian-labor-market/7-trendov-mirovogo-rynka-frilansa-363882 (data zvernennia : 05.10.2018). 8. Exploring the UK Freelance Workforce in 2016. URL: https://www.ipse.co.uk/uploads/assets/uploaded/de84dfb7-283a4c26-ba446f95f5547c1f.pdf (data zvernennia : 05.10.2018). 9. Global Contingent Workforce Study, EY. URL: https://gigeconomy.ey.com/ (data zvernennia : 05.10.2018). 10. Independent work: Choice, necessity, and the gig economy I McKinsey Global Institute, 2016. URL: https://www.mckinsey.com/ /media/McKinsey/Featured\%20Insights/Employ ment\%20and\%20Growth/Independent\%20work\%20Choice\%20necessity\%20a nd\%20the\%20gig\%20economy/Independent-Work-Choice-necessity-and-thegig-economy-Executive-Summary.ashx (data zvernennia : 05.10.2018).

Рецензент: д.е.н., професор Безтелесна Л.І. (НУВГП) 
Samoliuk N. M., Candidate of Economics (Ph.D.), Associated Professor (National University of Water and Environmental Engineering, Rivne), Kostiuk D. O., Member of the Rivne Junior Academy of Sciences of Student Youth

\section{STATE AND FORECASTS OF FREELANCE DEVELOPMENT IN UKRAINE}

In this article the key motives of freelance activity on the basis of the polls analysis of freelancers are considered. The tendencies of freelance market development in particular in the context of cities, are explored in Ukraine. It is described the division of Ukrainian freelancers according to the sphere of activity. The size and dynamics of pays of employees of this sphere of employment are analyzed. The main problems arising in the conditions of freelance activity are considered. Forecasts about freelance development in Ukraine by SWOT-analysis method are investigated.

Keywords: freelance, freelancer, form of employment, selfemployment, freelance-exchange.

Самолюк Н. Н., к.э.н., доцент (Национальный университет водного хозяйства и природопользования, г. Ровно), Костюк Д. А., член Ровенской Малой академии наук учащейся молодежи

\section{СОСТОЯНИЕ И ПЕРСПЕКТИВЫ РАЗВИТИЯ ФРИЛАНСА В УКРАИНЕ}

В данной статье рассмотрены основные мотивы фриланс- деятельности на основе анализа опросов фрилансеров. Исследованы тенденции развития рынка фриланса в Украине, в частности в разрезе городов. Охарактеризовано распределение украинских фрилансеров по сфере деятельности. Проанализированы размер и динамика заработка работников данной формы занятости. Рассмотрены основные препятствия, возникающие в условиях фриланс деятельности. Исследованы перспективы развития фриланса в Украине методом SWOT-анализа.

Ключевые слова: фриланс, фрилансер, форма занятости, самозанятость, фриланс-биржа. 